\title{
Article \\ Adoption of Durum Wheat Cultivar 'Salim' with a Technical Package and Its Resilience to Climate Change Impacts in Smallholders: Case of Nebeur/Kef Region, Tunisia
}

\author{
Sourour Ayed ${ }^{1, *,+}$, Saida Mlouhi ${ }^{2,+}$ and Imen Bouhaouel ${ }^{3}(\mathbb{D}$ \\ 1 Field Crops Laboratory, LR20-INRAT-02, National Agricultural Research Institute of Tunisia, \\ University of Carthage, Ariana 2049, Tunisia \\ 2 Rural Economy Laboratory, LR20-INRAT-07, National Agricultural Research Institute of Tunisia, \\ University of Carthage, Ariana 2049, Tunisia; saidamlouhi@gmail.com \\ 3 Genetics and Cereal Breeding Laboratory, LR14AGR01, National Agronomic Institute of Tunisia, \\ University of Carthage, Tunis 1082, Tunisia; imenbouhaouel@gmail.com \\ * Correspondence: ayedsourour@yahoo.fr \\ + These authors equally contributed joint first authors.
}

Citation: Ayed, S.; Mlouhi, S.; Bouhaouel, I. Adoption of Durum Wheat Cultivar 'Salim' with a Technical Package and Its Resilience to Climate Change Impacts in Smallholders: Case of Nebeur/Kef Region, Tunisia. Plants 2021, 10, 2379. https: / / doi.org/10.3390/ plants10112379

Academic Editors: Francisco Javier Cano Martin and Alexander Watson-Lazowski

Received: 17 September 2021 Accepted: 8 October 2021

Published: 5 November 2021

Publisher's Note: MDPI stays neutral with regard to jurisdictional claims in published maps and institutional affiliations.

Copyright: (c) 2021 by the authors. Licensee MDPI, Basel, Switzerland. This article is an open access article distributed under the terms and conditions of the Creative Commons Attribution (CC BY) license (https:// creativecommons.org/licenses/by/ $4.0 /)$.

\begin{abstract}
In recent years, there has been an urgent need for local strategies to ensure food sustainability in Tunisia, recognized as a climate change hotspot region. In this context, adaptation measures, including the adoption of high-yielding durum wheat cultivars with adequate agronomical practices, are an important avenue to improving the productivity of the smallholders that represent $80 \%$ of Tunisian farmers. Thus, this study highlights the impact of (i) the adoption of the recently marketed durum wheat cultivar 'Salim' as compared to the common cultivar 'Karim' and the transfer of a technical package to 11 farmers in the Nebeur delegation/Kef-Tunisia (semi-arid region) during the 2013/2014 and 2014/2015 cropping seasons, and (ii) climate change on the expected mean grain yield and biomass by 2070, using the CropSyst agronomic cultivation model based on multi-year crop simulations run with a daily weather series (2020-2070). The adoption of 'Salim' with the recommended package, compared to 'Karim' with the farmer practices, significantly increased the grain yield (37.84\%) and biomass (55.43\%). Otherwise, the impact of the $0.8{ }^{\circ} \mathrm{C}$ temperature rise on the potential yields and biomass over the next 51 years was positive. Contrary to expectations, the yield increases for the two cultivars were very close, but the yield of 'Salim' (36.02 q ha ${ }^{-1}$ ) remains much higher than that of 'Karim' (23.34 q ha $\left.{ }^{-1}\right)$. On other hand, 'Salim' experienced a higher increase for biomass compared to that of 'Karim'. These results indicate that the adoption of the 'Salim' cultivar with its technical package might be considered as a strategy of adaptation to Nebeur conditions and to future climate change events.
\end{abstract}

Keywords: CropSyst model; mitigation; semi-arid environment; simulation technical package; sustainability

\section{Introduction}

In recent years, durum wheat (Triticum durum Desf.) production has been threatened by climate change and the extreme weather events that pose a serious risk to social, economic, and political stability in the Mediterranean countries, particularly in Tunisia [1-3]. In fact, durum wheat is the staple food that provides the main import of calories $(258 \mathrm{~kg} /$ capita/year) in this country [3,4]. It is well known that the response of wheat to climate change varies between cultivars, years, pedological conditions, and agronomic management, thus highlighting the need to consider all these factors in climate change impact studies [3]. The influences of weather and climate on the different components of crop production can vary and often happen at the same time [5]. Furthermore, different types of climatic extremes can affect the crop production differently. This makes it difficult to understand the climatic impacts on the respective components of crop production. The 
increase in temperature in response to climate change raises the risk of heat stress and water demand during flowering time and boosts earlier and faster crop growth, thereby reducing yield $[6,7]$. On the other hand, higher temperature can reduce the risk of severe/late frost damage and thus leads to higher yield and biomass accumulation.

Stabilizing and increasing production under these conditions will be a real challenge for Tunisia, requiring an improvement in technical and economic efficiencies [8]. Accordingly, adaptation strategies that are resilient to such changes across different climates should be implemented immediately, and the government must take decisive action to ensure sustainable food production. From these measures, crop genetics and management strategies, such as technological advances, certified seeds and fertilizers, the adoption of new cultivar, and better farming practices, can be options to increase production by the smallholders that represent $80 \%$ of Tunisian farmers [9-11]. Several regions already showed large yield gaps caused by the lack of some of these components [12]. To boost the productivity of Tunisian farmers, especially in rainfed environments, great efforts were made by the national breeding program, resulting in the registering of several durum wheat cultivars in the national catalogue (e.g., 'Karim', 'Razzek', 'Om Rabiaa', 'Khiar', 'Nasr', 'Maali', and 'Salim') [13,14]. In particular, increasing yield genetic potential under water-deficit conditions is one of the major objectives and the principal selection index of the durum wheat breeding programs $[3,15,16]$. Promoting the adoption of high-yielding cultivars with the recommended practices in a sustainable manner helps to improve the livelihoods of rural farmers [17]. In particular, on-farm demonstrations, which are key to teaching in the extension system, gained the confidence of farmers who toured the farms, leading to the successful adoption of the package and the showing of new practices to the farmers [18]. Accordingly, there is a need for adoption studies to consider the farmers' perceptions of the technology attributes in the evaluation of the durum wheat cultivar adoption decisions.

According to Lobell et al. [19], the way to better understand the impacts of climate change on yields and to develop effective adaptation strategies is to assess the extent to which historical and recent crop yield trends have been affected by climate change. Several statistical models were used as reliable tools for the quantitative prediction of crop yield [20]. These crop-yield simulation models integrate knowledge on physiology, agronomy, soil science, and agro-meteorology in the models, using mathematical equations to quantitatively and dynamically describe the process of crop growth, development, and yield establishment [21-23]. Several studies have attempted to relate the climate to crop yields, with or without considering the technological advances at both the regional and the global scales [24]. A recent study predicted a strong decline in global wheat yields by $6.0 \pm 2.9 \%$ for each $1{ }^{\circ} \mathrm{C}$ of temperature rise due to climate change [25]. The estimated wheat-yield losses for the United States $\left(-5.5 \pm 4.4 \%\right.$ per $\left.1^{\circ} \mathrm{C}\right)$ and France $(-6.0 \pm 4.2 \%$ per $1^{\circ} \mathrm{C}$ ) are similar to the global average, while those for India $\left(-9.1 \pm 5.4 \%\right.$ per $\left.1{ }^{\circ} \mathrm{C}\right)$ and Russia $\left(-7.8 \pm 6.3 \%\right.$ per $\left.1{ }^{\circ} \mathrm{C}\right)$ are more vulnerable to temperature increase. Otherwise, Bahri et al. [8] reported that the durum wheat grain yield will increase differently in the semi-arid region (Kef region) according to agronomic scenarios for the considered time slices (2016-2035, 2045-2064, and 2075-2094). Taking all of these factors into account, the study of the degrees of effectiveness of the adaptation strategies in the future according to local conditions is required to obtain climate-smart and sustainable food systems.

Thus, the present investigation was designed to promote a mitigation strategy by (i) the adoption of 'Salim' cultivar, one of the recently marketed Tunisian durum wheat cultivars, chosen mainly for its yield potential and drought tolerance, and (ii) the transfer of the durum wheat technical package to the smallholders of the Nebeur/Kef region-Tunisia, located in the semi-arid area. The second aim was to analyze the current climate status and future projected climate changes on the adaptation of this cultivar with its recommended package from 2020 to 2070. In this study, the agronomic cultivation model, CropSyst, was selected to predict the grain yield and biomass over the next 51 years. 


\section{Results and Discussion}

\subsection{On-Farm Demonstration of 'Salim' Durum Wheat Cultivar}

As a first step, on-farm cultivar testing aims to assess the performance of the emerging and current cultivar 'Salim' in large plots as compared to that of the common cultivar 'Karim', using the same recommended technical package by all farmers (i.e., leader and satellites). In Tunisia, most farmers used the old cultivar 'Karim', characterized by its sensitivity to diseases (e.g., Septoria tritici blotch) (Table S2) [26], with the traditional agricultural practices, while only a few adopted some of the new durum wheat cultivars. Analysis of variance (ANOVA) showed significant differences in grain yield $(p<0.05)$ and biomass $(p<0.01)$ between 'Salim' and 'Karim' for the two cropping seasons, 2013/14 and 2014/15 (Figure 1). The highest mean grain yield and biomass were recorded for 'Salim' (34.52 and $100.19 \mathrm{q} \mathrm{ha}^{-1}$, respectively) compared to 'Karim' (28.55 and $90.23 \mathrm{q} \mathrm{ha}^{-1}$, respectively). Thus, the increase in terms of yield and biomass for the farmers who adopted 'Salim' cultivar is about $17.32 \%$ and $9.93 \%$, respectively. Our findings corroborate those of Tiwari et al. [27] and Bekele and Shiberu [28] who studied the adoption of improved wheat varieties by Indian and Ethiopian farmers. The adoption of the new cultivars depends on several factors, either directly or indirectly. Bekele and Shiberu [28] depicted that high cost and access to certified seeds, the lack of income of the farmers, and the low education level are the major constraints that negatively affect the adoption rate of the improved bread wheat varieties. In addition, farm and field characteristic variables, such as farm size, soil type, and animal power play significant roles in adoption decisions [29]. Nonetheless, the farmers' participation in the on-farm demonstration, training course and field day on wheat production, and the farmers' access to the extension service, might significantly affect the adoption rate of the recommended durum wheat cultivars.

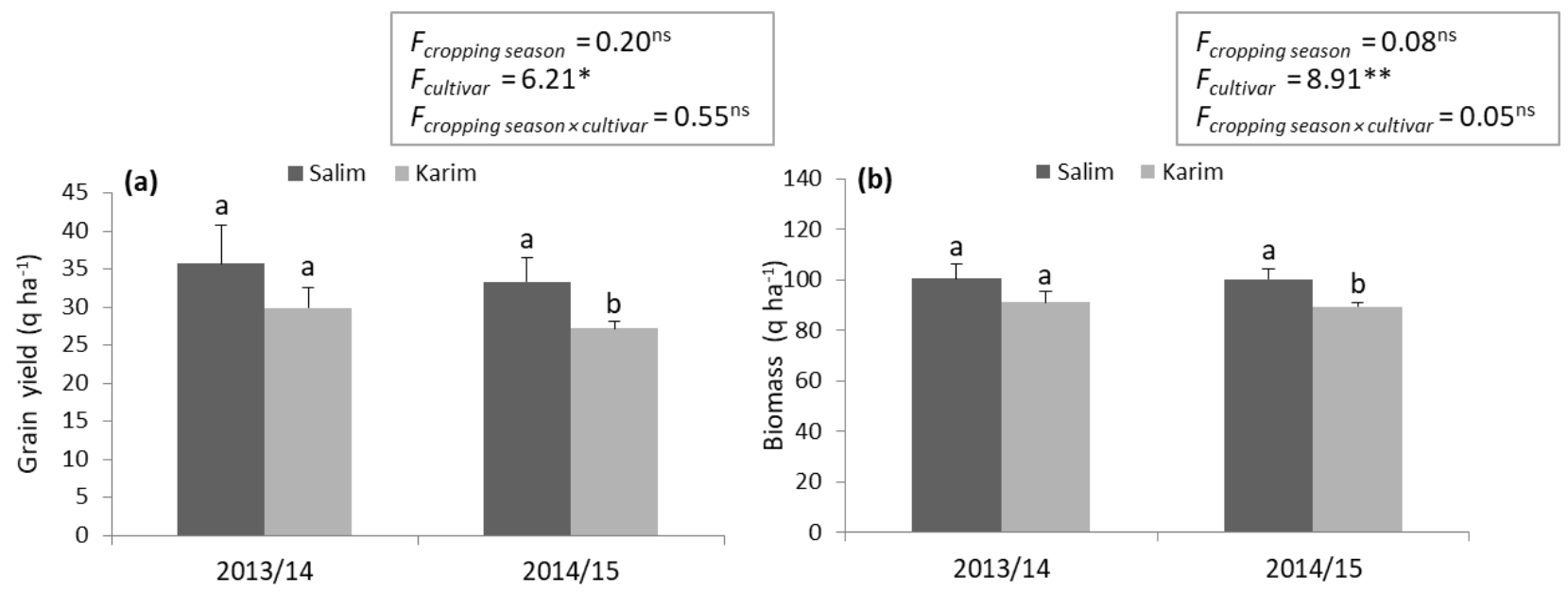

Figure 1. Effect of 'Salim' cultivar adoption based on mean grain yield (a) and biomass (b), compared to 'Karim' cultivar using the recommended technical package. Values represent the mean $\pm \mathrm{SD}$ and different letters indicate significant differences between cultivars at $p \leq 0.05$ (Tukey test) for each cropping season. F: F value; ns: non-significant; ${ }^{*}$ : significant at the level $0.05{ }^{* *}$ : significant at the level 0.01 .

\subsection{Transfer of Durum Wheat Technical Package}

The efficiency of the crop-production package was determined using the 'Salim' cultivar that had already showed better performance compared to 'Karim'. The results revealed significant variations $(p<0.01)$ between the demonstration package and the farmers' practices (Figure 2a,b). The mean grain yield and biomass of 'Salim' with the recommended package were clearly higher (34.52 and $100.19 \mathrm{q} \mathrm{ha}^{-1}$, respectively) than those obtained by the classical practices ( 24.46 and $56.99 \mathrm{q} \mathrm{ha}^{-1}$ ). For the two cropping seasons (2013/14 and 2014/15), the technical package increased the mean grain yield of 'Salim' by $29.17 \%$, and the biomass by $43.12 \%$. As expected, these results were achieved by 
improved management practices, including fertilizer application and the mechanization of weed, pest, and disease control. In the same context, Adzawla and Alhassan [30] found that among the climate adaptation strategies adopted by maize farmers, crop rotation and row planting were essential for sustainable food production in Northern Ghana. By comparing the farmers' practices to the recommended practices, Joshi et al. [31] reported that the demonstrated plot gave an additional yield of $6.67 \mathrm{q} \mathrm{ha}^{-1}$ and an increase in durum wheat productivity of about $18.22 \%$. Additionally, Tiwari et al. [27] mentioned that improved wheat technology increased yield with an average of $13.23 \mathrm{q} \mathrm{ha}^{-1}$. However, according to Eponou [32], only a small proportion of farmers (10\%) adopted all the components of the technology packages in Africa. Thus, further work is needed to encourage the traditional farmers to adopt the improved durum wheat technology.
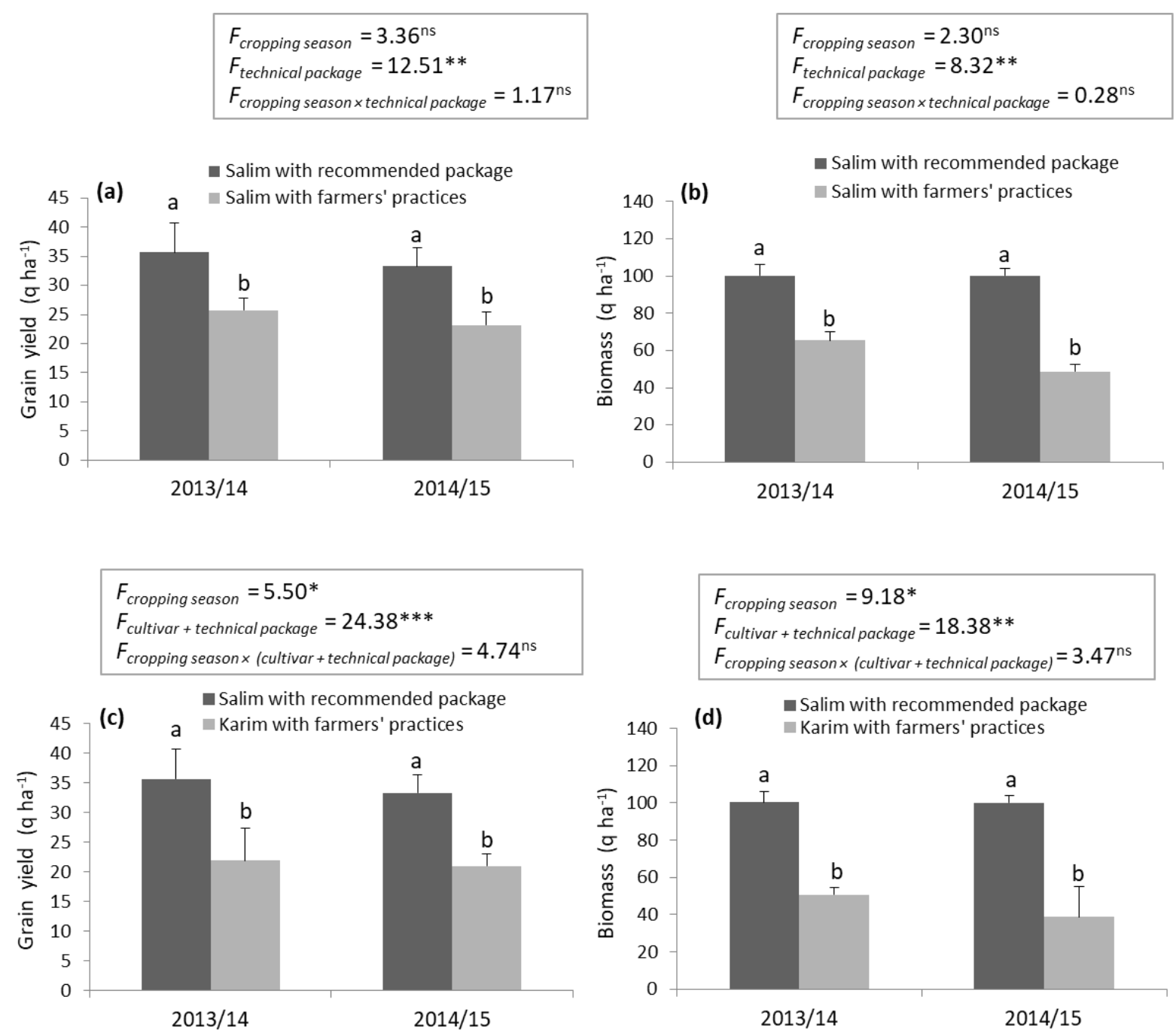

Figure 2. Effect of 'Salim' cultivar and technical package adoption based on mean grain yield (a,c) and biomass (b,d). Values represent the mean $\pm \mathrm{SD}$ and different letters indicate significant differences between technical package at $p \leq 0.05$ (Tukey test) for each cropping season. F: F value; ns: non-significant; *: significant at the level 0.05; ${ }^{* *}$ : significant at the level 0.01; ***: significant at the level 0.001 .

\subsection{Adoption of 'Salim' with the Recommended Technical Package vs. 'Karim' with Farmers' Practices}

To convince the farmers to abandon their usual practices and adopt new technologies, yield and biomass increases were estimated by comparing 'Salim' with the recommended package vs. 'Karim' with the farmers' practices. A significant difference $(p<0.01)$ was obtained between the technical itineraries for the two attributes (Figure 2c,d). Interestingly, the 
technical package proposed in this study ('Salim' cultivar, fertilizer, and weed and disease control) increased the mean grain yield and biomass by 37.84 and $55.48 \%$, respectively.

Yield gap was calculated as the difference between the yield levels using the recommended package and the yield levels using the existing farmers' practices. In our conditions, mean yield gaps of 13.82 and $12.36 \mathrm{q} \mathrm{ha}^{-1}$ were recorded for the 2013/14 and 2014/15 cropping seasons, respectively. These results were achieved through improved management practices, combined with the use of the new high-yielding cultivar. Although these farmers share the same agricultural practices (i.e., cultivar and technical package), differential yield gaps were observed for the considered farmers (Table S1). This variation might be attributed to some factors, such as soil type, the preceding crop, weed flora, etc. In the same sense, Joshi et al. [31] obtained mean wheat yield gaps ranging between 5.34 to $8.12 \mathrm{q} \mathrm{ha}^{-1}$ depending on the crop year. These authors suggest that the use of the improved method of wheat cultivation can reduce the technology gap (i.e., the difference between the potential yield and the demonstration yield) and increase wheat productivity. Large production increases from $45 \%$ to $70 \%$ are possible with the changing of management practices [10]. In particular, Bell et al. [33] reported that $48 \%$ of the gain was attributed to the increased use of $\mathrm{N}$ fertilizer. In conclusion, farmers are recommended to leave the classical practices in favor of the durum wheat package proposed by the project in order to improve their production and incomes.

\subsection{Generated Temperature and Precipitation}

The grain yield and biomass of 'Salim' and 'Karim' cultivars were simulated based on past weather data (1992-2019) and future weather scenarios (2021-2070). The generation of temperature by the crop system showed that the real mean maximum temperature will increase from $38.0^{\circ} \mathrm{C}$ during the period $1992-2019$ to $40.3^{\circ} \mathrm{C}$ during 2021-2070, an increase of $2.3^{\circ} \mathrm{C}$ (Figure 3). On the other hand, the mean minimum temperature for the same period (1992-2019) will drop from $11.8^{\circ} \mathrm{C}$ to $11.1^{\circ} \mathrm{C}$ around the 2070s, i.e., a decrease of $-0.7^{\circ} \mathrm{C}$ (generated temperature). Comparing the real mean of maximum and minimum temperatures, a temperature rise of $0.8{ }^{\circ} \mathrm{C}$ will be recorded at the end of the period considered by the temperature projection. Tunisia is already recognized as a climate change hotspot region in the Mediterranean Rim [34]. This is due to the location of the country, positioned between the inter-tropical regions and the temperate regions of the northern hemisphere, which makes its climate particularly variable. Our results are in accordance with those of the Intended Nationally Determined Contribution (INDC), which reported that the country is very exposed to climate change, characterized by an average temperature increase of $2.1^{\circ} \mathrm{C}$ by 2050 [35]. Assuming an overall temperature rise of $+2{ }^{\circ} \mathrm{C}$, Pillet et al. [36] also concluded that the annual temperature will increase from $+1.5^{\circ} \mathrm{C}$ to $+2.8^{\circ} \mathrm{C}$ from the north to the south of Tunisia during the period of 2031-2060. The seasonal increases will vary from $+1.7^{\circ} \mathrm{C}$ to $+2.8^{\circ} \mathrm{C}$ for autumn; from $+1.8^{\circ} \mathrm{C}$ to $+3.5^{\circ} \mathrm{C}$ for summer; from $+1.2{ }^{\circ} \mathrm{C}$ to $+2.2^{\circ} \mathrm{C}$ for spring; and from $+1.3^{\circ} \mathrm{C}$ to $+2.3^{\circ} \mathrm{C}$ for winter. Otherwise, by comparing sub-humid to semi-arid areas of Tunisia, Bahri et al. [8] reported that temperature increases of $1.5^{\circ} \mathrm{C}$ and $1.7^{\circ} \mathrm{C}$, respectively, will be projected over the period 2075-2094, as compared to 2016-2035.

Our analysis revealed that the mean of the real precipitation of $184 \mathrm{~mm}$ during the period 1992-2019 will increase to $344 \mathrm{~mm}$ by the 2070s, an increase of $160 \mathrm{~mm}$ (Figure 4). Easterling et al. [37] also showed changes in extreme events for future climates, such as increases in extreme high temperatures, decreases in extreme low temperatures, and increases in intense precipitation events. The same result was obtained by other climate model simulations showing that an increase in greenhouse gases produces increased surface heating with warmer surface temperatures and more evaporation [38]. This leads to an increase in the atmosphere's ability to hold more atmospheric moisture content with enhanced precipitation rates. The IPCC [39] mentioned that changes in precipitation in a warming world will not be uniform, and extreme precipitation events will become more intense and frequent in many regions. For instance, Liu et al. [40] reported that under the 
$1.5^{\circ} \mathrm{C}$ scenario in Central Asia, the mean annual total precipitation and heavy precipitation will experience increases of $7.68 \%$ and $26.55 \%$. Conversely, the INDC [35] predicted for Tunisia an increase in average temperature of $2.1^{\circ} \mathrm{C}$ and a $20 \%$ decrease in annual rainfall by 2050 . Bahri et al. [8] also noted that the cumulative rainfall for the three time slices considered (2016-2035, 2045-2064, and 2075-2094) is not going to change in the Kef region, while it will significantly decrease in the sub-humid area.

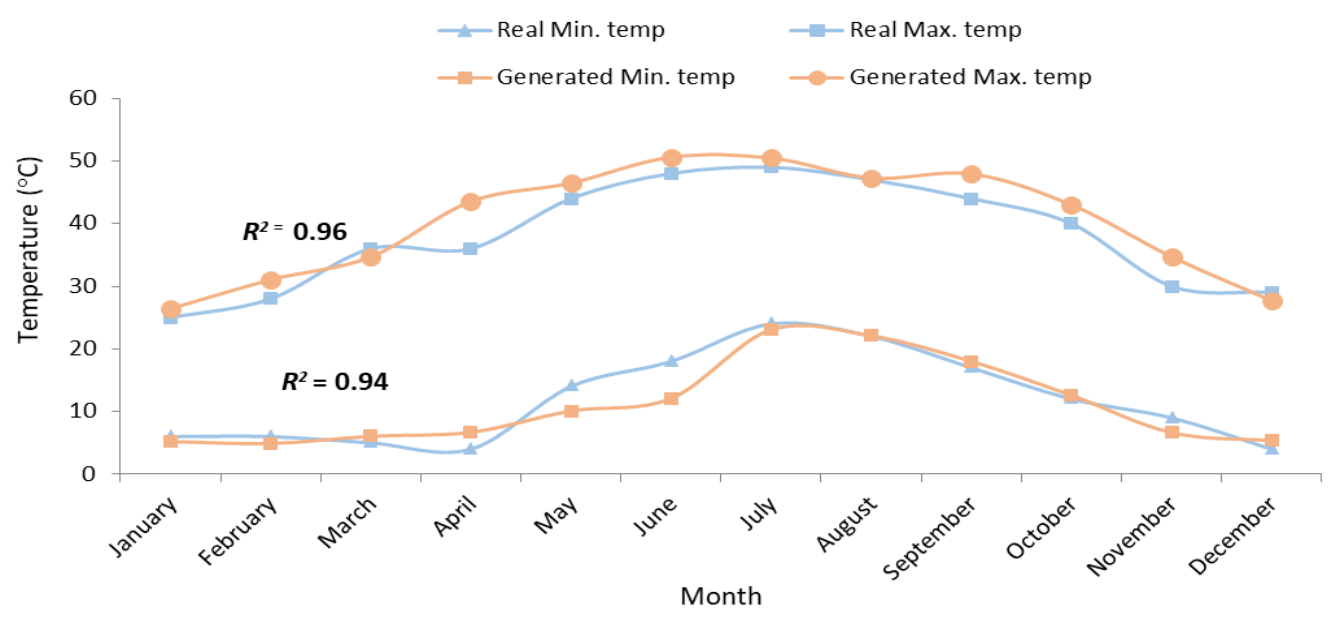

Figure 3. Real (1992-2019) vs. generated (2020-2070) mean temperature.

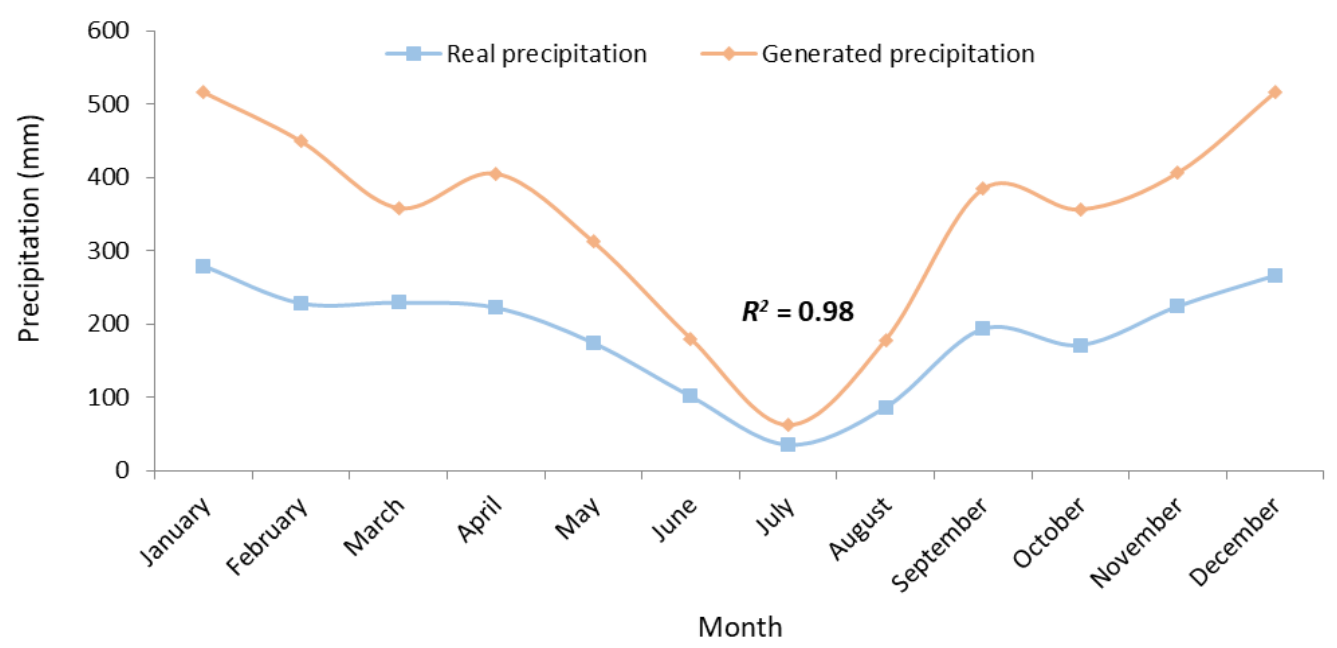

Figure 4. Real (1992-2019) vs. generated (2020-2070) precipitation.

A clearly close correspondence $\left(R^{2}>0.90\right)$ between the real and generated temperatures or precipitations (Figures 3 and 4 ) was obtained, indicating that ClimGen (subprogram in CropSyst model) adeptly generates climate data in the Tunisian conditions.

\subsection{Short-Term Grain Yield and Biomass Simulation}

A comparison between the observed yields (34.51 and $21.45 \mathrm{q} \mathrm{ha}^{-1}$ for 'Salim' and 'Karim', respectively) and the simulated yields (34.41 and $21.43 \mathrm{q} \mathrm{ha}^{-1}$ for 'Salim' and 'Karim', respectively) highlights the proximity of values (Figure 5). Similar to the grain yield, the values of the real $\left(44.66 \mathrm{q} \mathrm{ha}^{-1}\right)$ and the simulated biomass $\left(48.47 \mathrm{q} \mathrm{ha}^{-1}\right)$ of 'Karim' cultivar were very close. However, the simulated biomass of the 'Salim' cultivar $\left(121.19 \mathrm{q} \mathrm{ha}^{-1}\right)$ was higher than the observed biomass $\left(100.19 \mathrm{q} \mathrm{ha}^{-1}\right)$. In reality, and taking into account natural conditions, several factors negatively affect the yields, such as losses due to diseases, handling, transport, packaging, and storage. These factors are not modeled and might explain the variation between the real and simulated biomass as confirmed by Flichman and Jacquet [41]. 

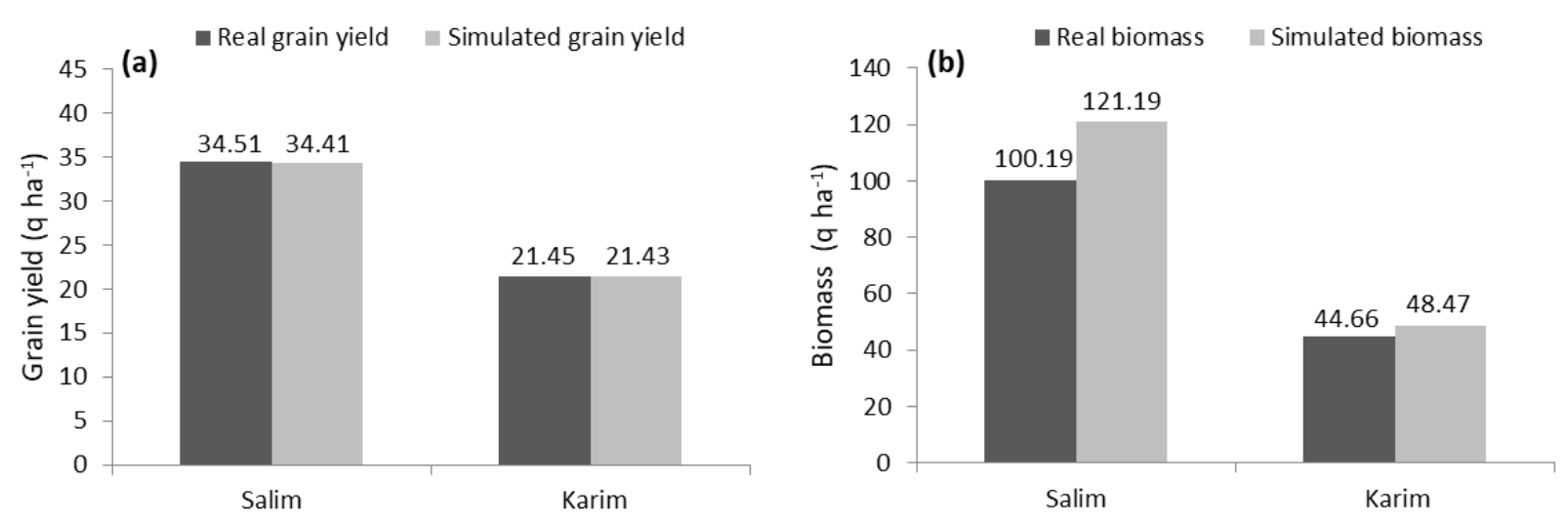

Figure 5. Real vs. simulated grain yield (a) and biomass (b) of 'Salim' and 'Karim' cultivars (2013/14 and 2014/15).

\subsection{Long-Term Grain Yield and Biomass Simulation}

The real yields of 'Salim' and 'Karim' were 34.51 and $21.45 \mathrm{q} \mathrm{ha}^{-1}$ (Figure 5), respectively, while the predicted yields over 2020-2070 (51 years) were 36.02 and $23.34 \mathrm{q} \mathrm{ha}^{-1}$ (Figure 6). Surprisingly, the mean yields increase by 4.19 and $8.09 \% \mathrm{ha}^{-1}$ for 'Salim' and 'Karim', respectively. A significant variation of grain yield was recorded for both cultivars. In fact, the simulated yield ranged by $24-49 \mathrm{q} \mathrm{ha}^{-1}$ for 'Salim' and 18-34 $\mathrm{q} \mathrm{ha}^{-1}$ for 'Karim'. For the biomass, the mean simulated biomasses for both varieties over 51 years are about $121.68 \mathrm{q} \mathrm{ha}^{-1}$ ('Salim') and $48.47 \mathrm{q} \mathrm{ha}^{-1}$ ('Karim') (Figure 6), while the observed values were $100.19 \mathrm{q} \mathrm{ha}^{-1}$ and $44.66 \mathrm{q} \mathrm{ha}^{-1}$, respectively (Figure 5). The mean biomasses will therefore experience increases of $17.66 \% \mathrm{ha}^{-1}$ for 'Salim' and $7.86 \% \mathrm{ha}^{-1}$ for 'Karim'. Long-term simulations have shown that the biomass of the 'Salim' cultivar ranged by 86-169 $\mathrm{q} \mathrm{ha}^{-1}$ and 'Karim' by $32-80 \mathrm{q} \mathrm{ha}^{-1}$. Hence, this study revealed that the incidence of future climate events positively affects the yield of local durum wheat cultivars. According to the time slices (2016-2035, 2045-2064, and 2075-2094) and the agronomic scenarios considered, Bahri et al. [8] also mentioned a differential increase in durum wheat grain yield in the semi-arid region (Kef region), ranging from $5-11 \%$ under zero-tillage and $11-26 \%$ under zero-tillage with residue retention, as compared to the conventional tillage management. Additionally, a $0.2{ }^{\circ} \mathrm{C}$ temperature rise during 2020-2058 is expected to increase the yields $\left(10.1-14.4 \% \mathrm{ha}^{-1}\right)$ and the biomass $\left(13.6-14.6 \% \mathrm{ha}^{-1}\right)$ of three Tunisian barley cultivars [42]. However, the impact of a $1{ }^{\circ} \mathrm{C}$ temperature rise was only positive for the yield of the 'Imen' barley cultivar. In general, the main mechanisms controlling the simulated wheat responses are the direct and indirect temperature effects on the wheat's phenological development. It is well known that warmer temperatures accelerate the plant growing cycle through advanced anthesis and maturity, thus resulting in smaller biomass accumulation and lower yields [7,43]. Several reports have noted the detrimental impact of extreme weather events and climate change on wheat productivity in the Mediterranean and Asian countries [44-46]. As predicted by Zhao et al. [25], wheat (6.0\% reduction in global yields) will be the second affected species by each degree-Celsius increase in global mean temperature after maize $(7.4 \%)$, while rice $(3.2 \%)$ and soybean $(3.1 \%)$ showed lower rates of increase. Nonetheless, an increase in atmospheric carbon dioxide $\left(\mathrm{CO}_{2}\right)$ would have a fertilizing effect, especially when the temperature increase is less than $3{ }^{\circ} \mathrm{C}[47,48]$. Middle and high latitudes, as shown in the Nebeur region (latitude: $36^{\circ} 17^{\prime}$ ), and rainfall changes will be beneficial to increased crop yields [40,49]. In addition, the presence of aerosols in the atmosphere (e.g., sulfur aerosol), limiting the rise in temperature, reduces the yields' lowering but increases their variability [50]. This could thus rebalance the situation by limiting the harmful effect of a temperature rise. Rosenzweig and Tubiello [51] also concluded that the negative effects of temperature on simulated wheat yields might be reduced when minima increase more than maxima. However, in our case, the temperature minima decreased $\left(-0.7^{\circ} \mathrm{C}\right)$, while the maxima increased $\left(2.3^{\circ} \mathrm{C}\right)$, and precipitation showed an increase (Figure 6). 

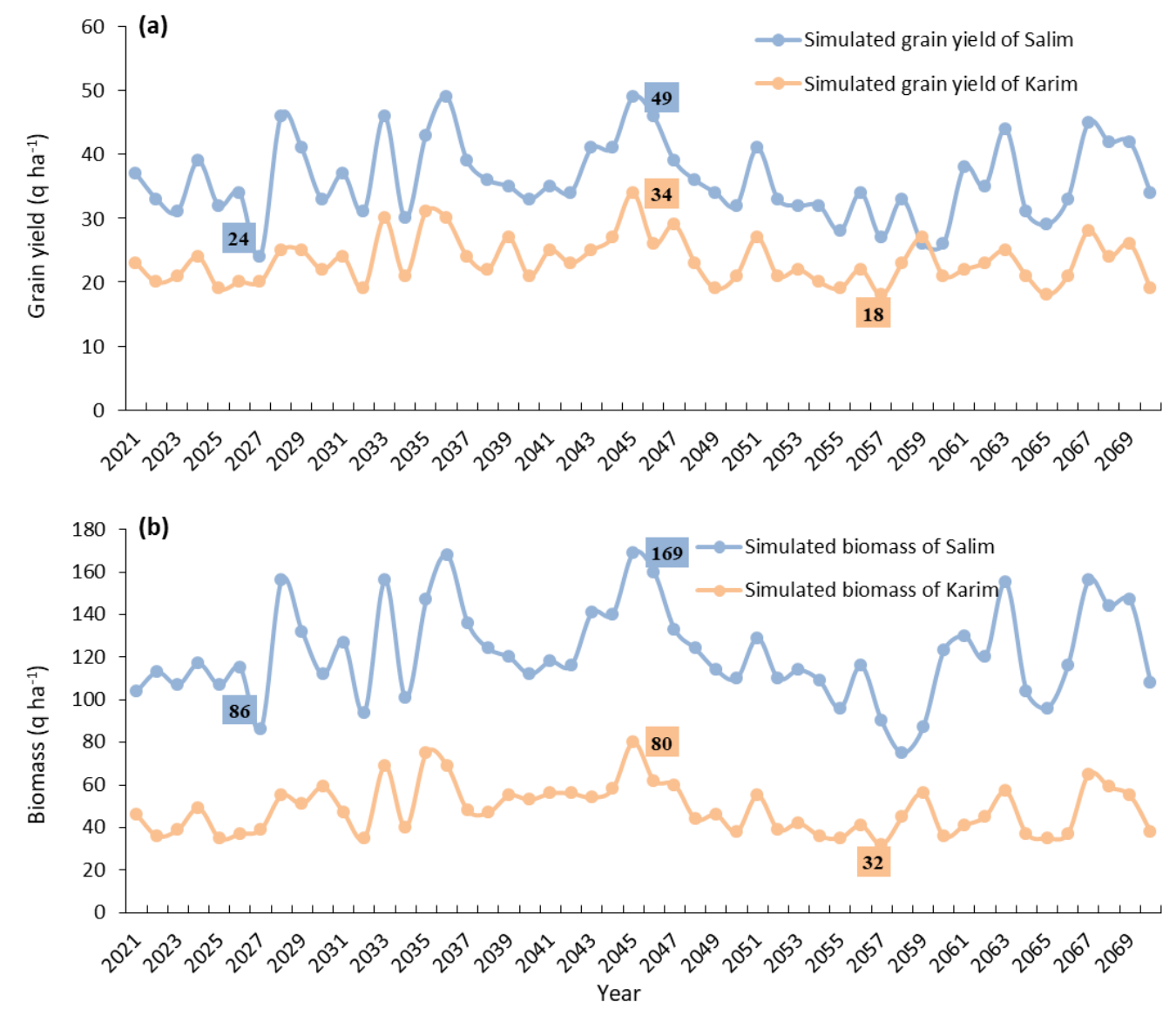

Figure 6. Simulated grain yield (a) and biomass (b) (2020-2070) of 'Salim' and 'Karim' cultivars.

Different strategies may be adopted to reduce the risk of crop exposure to extreme events, including the choice of the genetic material. Considering the two durum wheat cultivars, 'Salim' yield potential was still much higher compared to that of 'Karim', but the increase in grain yield is very close (1.51 and $1.89 \mathrm{q} \mathrm{ha}^{-1}$ for 'Salim' and 'Karim', respectively). This trend might be explained by the precocity of 'Karim' compared to 'Salim' (Table S2). Several authors pointed out that the use of wheat cultivars with a shorter growing cycle and early flowering can escape extreme climate events and thus result in a winning strategy for higher yields [7,52]. In contrast, Asseng et al. [53] indicated that a prolonged vegetative growth may better compensate for the reduced growing season length induced by higher temperatures. Otherwise, 'Salim' experienced a greater increase in biomass than 'Karim'. Indeed, the 'Salim' cultivar is characterized by denser vegetation than 'Karim' (Table S2). In addition, 'Salim' showed an extended stay-green attribute compared to the control cultivar which might explain its better drought tolerance. In conclusion, the adoption of the 'Salim' cultivar associated with the recommended package could be a good strategy for adaptation to climate change. Given the significant role played by the extension and the access-related variables, increased emphasis on information dissemination, field demonstrations, the farmers' participatory research, and training programs to popularize the new durum wheat cultivars and enhance their adoption rate are required. This also suggests that policy intervention should be made on improving the educational status of farming households and developing programs on a varietal package of durum wheat seed.

\section{Materials and Methods}

\subsection{Site Description and Meteorological Data Collection}

The experiments were conducted during two consecutive growing seasons, 2013/14 and $2014 / 15$, in the Nebeur/Kef delegation $\left(36^{\circ} 17^{\prime} 47^{\prime \prime} \mathrm{N}, 8^{\circ} 45^{\prime} 58^{\prime \prime} \mathrm{E}\right.$, at $390 \mathrm{~m}$ ), located in 
the northwest of Tunisia. Before sowing, soil was collected over a $1 \mathrm{~m}$ depth and showed a sandy clay loam texture (59.7\% sand, $26 \%$ clay, and $14.3 \%$ silt) [54], a cation exchange of $10 \mathrm{meq} 100 \mathrm{~g}^{-1}$, and $\mathrm{pH}=7.90$. The growing season precipitation and temperature data were recorded at the meteorological station of the Kef region (Figure 7). The region is subject to a semi-arid climate. An observed daily series of the maximum and minimum air temperature, the precipitation, solar radiation, the maximum and minimum relative humidity, and the wind speed of the 28 years from 1992 to 2019 were also collected from the same station. During this period, the means of the maximum and minimum air temperature and precipitation were $38.0^{\circ} \mathrm{C}, 11.8^{\circ} \mathrm{C}$, and $184 \mathrm{~mm}$, respectively (Figure S1).

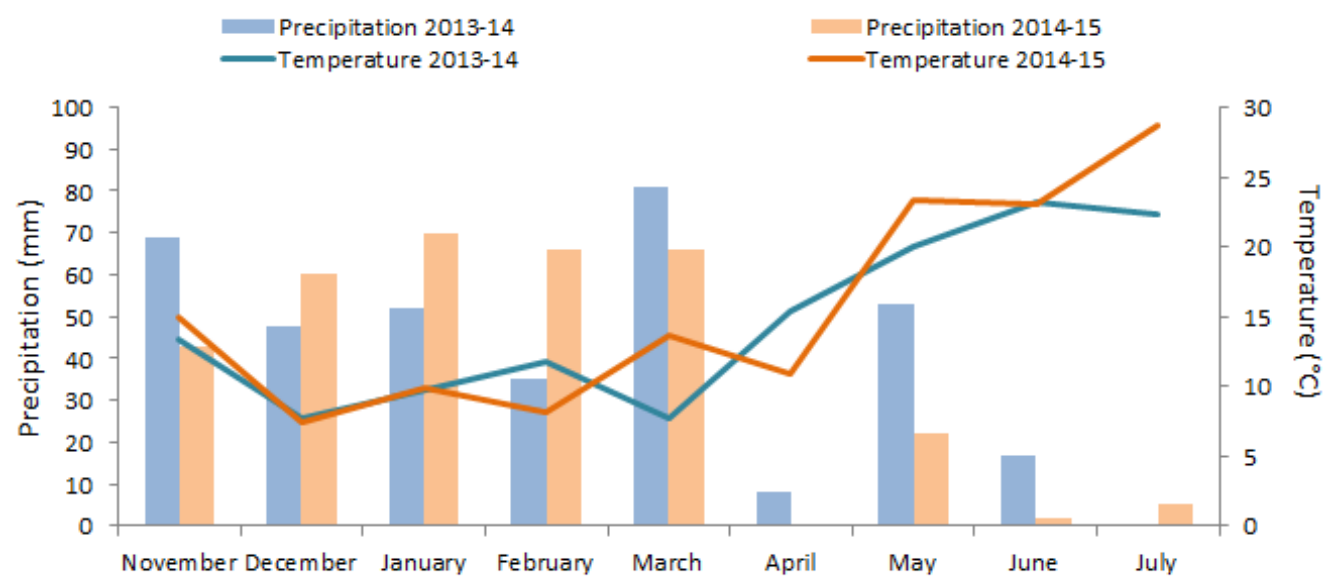

Figure 7. Monthly precipitation and temperature recorded in Nebeur/Kef site during 2013/14 and 2014/15 cropping seasons.

\subsection{Experimental Procedures}

Eleven farmers (leader and satellite farmers) were chosen in collaboration with Regional Agriculture Office Staff. The leader was selected based on his social relationship, his willingness to test and eventually to adopt new technologies, and his skill in communicating with the other farmers. All interventions (i.e., soil preparation, sowing, fertilization, weed and disease control, and harvesting) were conducted in the leader farmer's field in the presence of the entire group (i.e., satellite farmers and extension agents). During the crop development, all the farmers monitored the incidence of diseases and pests and learned when they should apply chemicals. The aim of this experiment was an on-farm demonstration of durum wheat (Triticum durum Desf.) 'Salim' cultivar with an appropriate technical package using a participatory method. 'Salim', released in 2009 and marketed to farmers in 2019, is recognized as a drought-tolerant genotype (Table S2). This cultivar was compared to 'Karim', the most widely grown cultivar in Tunisia, released in 1980 but cultivated since 1973 (i.e., old cultivar). Each farmer (i.e., of the leader and satellite farmers) tested the two cultivars with the recommended package and the farmers' usual practices. The difference between the demonstration package and the farmers' practices is given in Table 1. During the two cropping seasons, 2013/14 and 2014/15, Septoria tritici blotch symptoms were developed in early April, in particular on 'Karim'. Thus, Falcon (Tébuconazole + triadiménol+ spiroxamine) was recommended as a fungicide at a rate of $11 \mathrm{ha}^{-1}$ at the heading stage (Z51) [55]. Weeds were also chemically controlled using Puma ${ }^{\circledR}$ evolution (fenoxaprop-p-ethyl + iodosulfuron-methyl sodium + mefenpyr-diethyl) (Bayer CropScience, Beja, Tunisia), at a rate of $11 \mathrm{ha}^{-1}$ at the $2-3$ leaf stage (Z13). 
Table 1. Technical itineraries used in demonstration plots and farmers' plots during 2013/14 and 2014/15 cropping seasons.

\begin{tabular}{|c|c|c|c|}
\hline Cultural Operation & Growth Stage & Technical Package & Farmers' Practices \\
\hline Sowing date & & Last week of November & Last week of November \\
\hline Rate of sowing & - & $160 \mathrm{~kg} \mathrm{ha}^{-1}$ & $160 \mathrm{~kg} \mathrm{ha}^{-1}$ \\
\hline Sowing depth & & $1.2 \mathrm{~cm}$ & $1.2 \mathrm{~cm}$ \\
\hline Weed control & 2-3 leaf stage (Z13) & Weed control & No weed control \\
\hline Disease control & Heading stage (Z51) & Disease control & No disease control \\
\hline \multirow{4}{*}{ Fertilization } & At sowing & $\begin{array}{l}100 \mathrm{~kg} \mathrm{ha}^{-1} \text { Di-ammonium phosphate }(18 \% \\
\left.\mathrm{N} \text { and } 46 \% \mathrm{P}_{2} \mathrm{O}_{5}\right)\end{array}$ & $\begin{array}{c}100 \mathrm{~kg} \mathrm{ha}^{-1} \text { Di-ammonium } \\
\text { phosphate }\left(18 \% \mathrm{~N} \text { and } 46 \% \mathrm{P}_{2} \mathrm{O}_{5}\right)\end{array}$ \\
\hline & 3-4 leaf stage (Z14) & $100 \mathrm{~kg} \mathrm{ha}^{-1}$ ammonium nitrate (N 33.5\%) & - \\
\hline & Beginning of tillering (Z21) & $100 \mathrm{~kg} \mathrm{ha}^{-1}$ ammonium nitrate (N 33.5\%) & $100 \mathrm{~kg} \mathrm{ha}^{-1}$ ammonium (N 33.5\%) \\
\hline & Heading stage (Z51) & $150 \mathrm{~kg} \mathrm{ha}^{-1}$ ammonium nitrate (N $33.5 \%$ ) & - \\
\hline Irrigation & & Rainfed & \\
\hline
\end{tabular}

\subsection{Plant Measurements}

At maturity, two agronomic traits were measured from the eleven field experiments: grain yield ( $\mathrm{q} \mathrm{ha}{ }^{-1}$ ) and biomass $\left(\mathrm{q} \mathrm{ha}^{-1}\right.$ ). The analysis of variance (ANOVA) for each trait was performed using $\mathrm{R}$ statistical software version 4.0 (The $\mathrm{R}$ Foundation for Statistical Computing). The results obtained were used as a control to estimate the potential impact of climate change on the expected mean yield and the biomass by 2070 , under the pedological conditions of the Nebeur region.

\subsection{CropSyst Model Description}

The crop growth model, CropSyst (version 3_04_08) was designed to determine the most appropriate form of durum wheat function response and its interaction with the surrounding environment and management [56]. This model operates at a daily time and the law of limiting factors (e.g., water, salt, and nitrogen stress) intervenes to determine the potential yield. Cropsyst was used for its ability to simulate durum wheat yields for several consecutive years and to establish the relationship between input and output for the durum wheat production with a range of management and weather scenarios [57]. The yield and biomass and their changes over time were analyzed.

\subsection{Input Data and Weather Generation}

As described by Stöckle and Nelson [58], the grain yield and biomass were simulated based on: (i) the simulation control (cultivar and technical package) based on field experiments; (ii) the soil file (soil texture, cation exchange capacity, and chemical characteristics) necessary to calculate the hydraulic properties and the soil water balance (runoff, infiltration, and evaporation) by the model; (iii) the position file (altitude, latitude, stiffness, slope length in addition to the climatic data [minimum and maximum temperature, precipitation, wind speed, minimum and maximum of relative humidity, and solar radiation of 28 years from 1992 to 2019]); (iv) the crop file describing the properties of the two durum wheat cultivars (e.g., GDD, degree day emergence, specific leaf area; Table S2); (v) and the management file including all the technical itineraries (e.g., sowing, fertilization, weed control; Table 1). The crop module includes the most sensitive parameters that are grouped by function, namely classification, sowing, growth, morphology, phenology, vernalization, photoperiod, dormancy, harvest, residues, nitrogen nutrition, sensitivity to salts, etc. The default values for a number of crop types are provided by Cropsyst and may need to be adjusted for local cultivars. Some parameters of the durum wheat cultivars were collected from the literature or estimated by specialists' calculations.

Climate change, combined with other factors surrounding crops, might alter durum wheat conditions in the future; thus, daily weather series (2020-2070) were produced via the ClimGen weather generator of Cropsyst [57]. These series were derived from the observed weather parameters (1992-2019). We quote the main parameters (i.e., temperature and precipitation) on which this work is based. The released simulations were re-started each year after harvest using the soil water content for the 51 years of weather data (2020-2070) calculated using the initial soil water profile. 


\subsection{Short-Term Yield and Biomass Simulations}

Following the work of collecting data relating to the durum wheat cultivars and package, we applied, in a first step, a crop-based model for each durum wheat cultivar combined with its package. Simulations were carried out short-term over two years, 2013/14 and 2014/15. This period was chosen based on the availability of the real yield and biomass for both durum wheat cultivars ('Salim' and 'Karim'), which were considered as control data for the calibration and validation of the crop model. The first results obtained showed that the simulated yields approximated the observed yields for each cultivar with slight differences. These differences led us to act on certain physiological parameters of the wheat cultivars (growth, morphology, and phenology) to bring the simulated yields closer to the real yields. The model validation is a comparison between the outputs of the model and the perceived reality by an independent series of results. The validated short-term models were used for the long-term simulations over 51 years.

\subsection{Long-Term Yield and Biomass Simulations}

Once validated, the basic models were used for the long-term simulations, keeping the same cultivation techniques adopted by the farmers and using the climatic data generated from 2020 to 2070 to analyze the behavior and response of the two durum wheat cultivars, and the climate change impact on the yield and biomass.

\section{Conclusions}

This case study highlights the effect of the adoption of the 'Salim' cultivar and the recommended technical package on the grain yield and biomass. Interestingly, this cultivar performed better than the common cultivar, 'Karim'. We also demonstrated that the use of 'Salim' with the proposed package markedly enhanced the yield and biomass compared to that of 'Karim' with the farmers' usual practices. Otherwise, the generated climate change projections indicate $+2.3^{\circ} \mathrm{C}$ in maximum temperature, $-0.7^{\circ} \mathrm{C}$ in minimum temperature, and an increase of $160 \mathrm{~mm}$ in precipitation over the next 51 years (2021-2070). Surprisingly, this change positively affected the yield and biomass of 'Salim' conducted with the new technical package. Subsequently, this adoption could be an alternative to mitigate climate change impacts in future scenarios for the Nebeur region. Such results ultimately help farmers to develop more profit-oriented behaviors, which are necessary to enhance adoption rate, production, and food security in the long term. This strategy could be applied to formulate spatially targeted adaptation methods to large areas of North Africa with similar environmental characteristics for sustainable farming systems.

Supplementary Materials: The following are available online at https: / www.mdpi.com/article / 10.3390/plants10112379/s1: Figure S1-monthly precipitation (a) and temperature (b) recorded in Nebeur/Kef site during 1992-2019, Table S1—quantification of on-farm yield gap for all farmers, Table S2-characteristics of selected durum wheat cultivars, 'Salim' and 'Karim'.

Author Contributions: Conceptualization, S.A., S.M. and I.B.; methodology, S.A., S.M. and I.B.; software, S.M., I.B. and S.A.; validation, I.B., S.A. and S.M.; formal analysis, I.B., S.A. and S.M.; investigation, S.A., S.M. and I.B.; resources, S.A. and S.M.; data curation, S.A., S.M. and I.B.; writing-original draft preparation, S.A. and S.M.; writing-review and editing, S.A., S.M. and I.B.; visualization, S.A., S.M. and I.B.; supervision, S.A. and S.M.; project administration, S.A.; funding acquisition, S.A. All authors have read and agreed to the published version of the manuscript.

Funding: This research received no external funding.

Institutional Review Board Statement: Not applicable.

Informed Consent Statement: Not applicable.

Data Availability Statement: Available upon reasonable request. 
Acknowledgments: The work presented here was supported in part by Kef Regional Agriculture Office Staff. This work was also supported by the Ministry of Agriculture and the Ministry of Higher Education and Scientific Research. This research was supported also by the EU-IFAD (COFIN-ECG56-ICARDA) project entitled 'Enhanced small-holder wheat-legume cropping systems to improve food security under changing climate in the drylands of North Africa and West Asia (2012-2015)'.

Conflicts of Interest: The authors declare no conflict of interest.

\section{References}

1. Sabella, E.; Aprile, A.; Negro, C.; Nicolì, F.; Nutricati, E.; Vergine, M.; Luvisi, A.; De Bellis, L. Impact of climate change on durum wheat yield. Agronomy 2020, 10, 793. [CrossRef]

2. Beres, B.L.; Rahmani, E.; Clarke, J.M.; Grassini, P.; Posniak, C.J.; Geddes, C.M.; Porker, K.D.; May, W.E.; Ranson, J.K. A systematic review of durum wheat: Enhancing production systems by exploring genotype, environment, and management $(\mathrm{G} \times \mathrm{E} \times \mathrm{M})$ synergies. Front. Plant Sci. 2020, 11, 568657. [CrossRef] [PubMed]

3. Sadok, W.; Schoppach, R.; Ghanem, M.E.; Zucca, C.; Sinclair, T.R. Wheat drought-tolerance to enhance food security in Tunisia, birthplace of the Arab Spring. Eur. J. Agron. 2019, 107, 1-9. [CrossRef]

4. Chahed, Y. Tunisia Grain, Grain and Feed Annual; Grain Report; USDA Foreign Agriculture Service: Washington, DC, USA, 2009.

5. Lizumia, T.; Ramankutty, N. How do weather and climate influence cropping area and intensity? Glob. Food Sec. 2015, 4, 46-50.

6. Sommer, R.; Glazirina, M.; Yuldashev, T.; Otarov, A.; Ibraeva, M.; Martynova, L.; Bekenov, M.; Kholov, B.; Ibragimov, M.; Kobilov, R.; et al. Impact of climate change on wheat productivity in Central Asia. Agric. Ecosyst. Environ. 2013, 178, 78-99. [CrossRef]

7. Moriondo, M.; Bindi, M.; Brilli, L.; Costafreda-Aumedes, S.; Dibari, C.; Leolini, L.; Padovan, G.; Trombi, G.; Karali, A.; Varotsos, K.V.; et al. Assessing climate change impacts on crops by adopting a set of crop performance indicators. EMJE 2021, 6, 45 .

8. Bahri, H.; Annabi, M.; M'Hamed, H.C.; Frija, A. Assessing the long-term impact of conservation agriculture on wheat-based systems in Tunisia using APSIM simulations under a climate change context. Sci. Total. Environ. 2019, 692, 1223-1233. [CrossRef]

9. Richardson, J.G. On-farm demonstrations: Consideration factors for their success and viability as an extension teaching tool. SASAE 2003, 32, 114-124.

10. Mueller, N.D.; Gerber, J.S.; Johnston, M.; Ray, K.D.; Ramankutty, N.; Foley, J.A. Closing yield gaps through nutrient and water management. Nature 2013, 490, 254-257. [CrossRef] [PubMed]

11. El Harizi, K.; Sparacino, C.; M’Barek, S.B. Tunisie: Quel Avenir Pour les Cooperatives Agricoles? Organisation des Nations Unies Pour l'Alimentation et l'Agriculture: Rome, Italy, 2019; pp. 69-78.

12. Neumann, K.; Verburg, P.H.; Stehfest, E.; Müller, C. The yield gap of global grain production: A spatial analysis. Agric. Syst. 2010, 103, 316-326. [CrossRef]

13. Deghaïs, M.; Kouki, M.; Gharbi, M.; El Felah, M. Les Variétés de Céréales Cultivées en Tunisie (blé Dur, blé Tendre, orge et Triticale); Ministère de l'Agriculture et des Ressources en Eau: Tunis, Tunisie, 2007; pp. 1-445.

14. Ayed, S.; National Agricultural Research Institute of Tunisia, Ariana, Tunisia. Personal communication, 2021.

15. Mwadzingeni, L.; Shimelis, H.; Dube, E.; Laing, M.D.; Tsilo, T.J. Breeding wheat for drought tolerance: Progress and technologies. J. Integr. Agric. 2016, 15, 935-943. [CrossRef]

16. Sheshshayee, S.M.; Vijayaraghavareddy, P.; Sreevathsa, R.; Rajendrareddy, S.; Arakesh, S.; Bharti, P.; Dharmappa, P.; Soolanayakanahally, R. Introgression of physiological traits for a comprehensive improvement of drought adaptation in crop plants. Front. Chem. 2018, 6, 92.

17. Asfaw, S.; Shiferaw, B.; Simtowe, F.; Lipper, L. Impact of modern agricultural technologies on smallholder welfare: Evidence from Tanzania and Ethiopia. Food Policy 2012, 37, 283-295. [CrossRef]

18. Aggarwal, P.K.; Hebbar, K.B.; Venugopalan, M.V.; Rani, S.; Bala, A.; Biswal, A.; Wani, S.P. Quantification of Yield Gaps in Rain-Fed Rice, Wheat, Cotton and Mustard in India. Global Theme on Agroecosystems Report No. 43; International Crops Research Institute for the Semi-Arid Tropics: Andhra Pradesh, India, 2008; pp. 1-36.

19. Lobell, D.B.; Schlenker, W.; Costa-Roberts, J. Climate trends and global crop production since 1980. Science 2011, 333, 616-620. [CrossRef] [PubMed]

20. Shi, W.; Tao, F.; Zhang, Z. A review on statistical models for identifying climate contributions to crop yields. J. Geogr. Sci. 2013, 23, 567-576. [CrossRef]

21. Ahmad, I.; Saeed, U.; Fahad, M.; Ullah, A.; Habib ur Rahman, M.; Ahmad, A.; Judge, J. Yield forecasting of spring maize using remote sensing and crop modeling in Faisalabad-Punjab Pakistan. J. Indian Soc. Remote. Sens. 2018, 46, 1701-1711. [CrossRef]

22. ur Rahman, M.H.; Ahmad, A.; Wang, X.; Wajid, A.; Nasim, W.; Hussain, M.; Ahmad, B.; Ahmad, I.; Ali, Z.; Ishaque, W.; et al. Multi-model projections of future climate and climate change impacts uncertainty assessment for cotton production in Pakistan. Agric. For. Meteorol. 2018, 253, 94-113. [CrossRef]

23. Vanli, O.; Ustundag, B.B.; Ahmad, I.; Hernandez-Ochoa, I.M.; Hoogenboom, G. Using crop modeling to evaluate the impacts of climate change on wheat in southeastern turkey. Environ. Sci. Pollut. Res. 2019, 26, 29397-29408. [CrossRef]

24. Najafi, E.; Devineni, N.; Khanbilvardi, R.M.; Kogan, F. Understanding the changes in global crop yields through changes in climate and technology. Earth's Future 2018, 6, 410-427. [CrossRef] 
25. Zhao, C.; Liu, B.; Piao, S.; Wang, X.; Lobell, D.B.; Huang, Y.; Huang, M.; Yao, Y.; Bassu, S.; Ciais, P.; et al. Temperature increase reduces global yields of major crops in four independent estimates. Proc. Natl. Acad. Sci. USA 2017, 114, 9326-9331. [CrossRef] [PubMed]

26. Berraies, S.; Ammar, K.; Gharbi, M.S.; Yahyaoui, A.; Rezgui, S. Quantitative inheritance of resistance to Septoria tritici blotch in durum wheat in Tunisia. Chil. J. Agric. Res. 2014, 74, 35-40. [CrossRef]

27. Tiwari, A.; Choudhary, S.; Manjhi, P.; Swarnakar, V.K. Compare the yield of wheat varieties provided under NAIP (National Agricultural Innovation Project) through IARI (Indian Agricultural Research Institute) in Dhar district of Madhya Pradesh, India. J. Agric. Vet. Sci. 2014, 7, 37-40. [CrossRef]

28. Bekele, M.; Shiberu, T. Adoption of improved bread wheat varieties on small-scale farmers: The case of Boji Gebisa Ambo District, Oromia Regional State, Ethiopia. Am. J. Food Sci. Technol. 2014, 2, 103-108. [CrossRef]

29. Ghimire, R.; Huang, W.; Shrestha, R.B. Factors affecting adoption of improved rice varieties among rural farm households in Central Nepal. Rice Sci. 2015, 22, 35-43. [CrossRef]

30. Adzawla, W.; Alhassan, H. Effects of climate adaptation on technical efficiency of maize production in Northern Ghana. Agric. Food Econ. 2021, 9, 14. [CrossRef]

31. Joshi, N.S.; Bariya, M.K.; Kunjadia, B.B. Yield gap analysis through front line demonstration in wheat crop. Int. J. Sci. Res. 2014, 4, 1-3.

32. Eponou, T. Linkage between research and technology users: Some issues from Africa. ISNAR Brief. Pap. 1996, 30, 1-8.

33. Bell, M.A.; Fischer, R.A.; Byerlee, D.; Sayre, K. Genetic and agronomic contributions to yield gains: A case study for wheat. Field Crop. Res. 1995, 44, 55-65. [CrossRef]

34. Amamou, H.; Ben Sassi, M.; Aouadi, H.; Khemiri, H.; Mahouachi, M.; Beckers, Y.; Hammami, H. Climate change-related risks and adaptation strategies as perceived in dairy cattle farming systems in Tunisia. Clim. Risk Manag. 2018, 20, 38-49. [CrossRef]

35. INDC (Intended Nationally Determined Contribution). United Nations Framework Convention on Climate Change: Intended Nationally Determined Contribution of Tunisia; Ministry of Environment and Sustainable Development: Tunis, Tunisia, $2015 ;$ pp. 1-18.

36. Pillet, G.; King, L.; Nasr, Z.; Almohamad, H.; Maag, C.C.; Lahache Gafrej, R.; Yaalaoui, E.; Neff, C.; El Hamrouni, A.; Aloui, A.; et al. Etude: Stratégie Nationale D'adaptation de L'Agriculture Tunisienne et des Écosystèmes aux Changements Climatiques; Deutsche Gesellschaft für Internationale Zusammenarbeit (GIZ) GmbH: Tunis, Tunisia, 2007; pp. 1-165.

37. Easterling, D.R.; Meehl, G.A.; Parmesan, C.; Changnon, S.A.; Karl, T.R.; Mearns, L.O. Climate extremes: Observations, modeling, and impacts. Science 2000, 289, 2068-2074. [CrossRef] [PubMed]

38. Trenberth, K.E. Conceptual framework for changes of extremes of the hydrological cycle with climate change. Clim. Chang. 1999, 42, 327-339. [CrossRef]

39. IPCC (Intergovernmental Panel on Climate Change). Climate Change 2014: Synthesis Report. Contribution of Working Group I, II and III to the Fifth Assessment Report of the Intergovernmental Panel on Climate Change; IPCC: Geneva, Switzerland, $2014 ;$ pp. 56-74.

40. Liu, Y.; Geng, X.; Hao, Z.; Zheng, J. Changes in climate extremes in Central Asia under 1.5 and $2{ }^{\circ} \mathrm{C}$ global warming and their impacts on agricultural productions. Atmosphere 2020, 11, 1076. [CrossRef]

41. Flichman, G.; Jacquet, F. Couplage de modèles agronomiques et économiques: Intérêts pour l'analyse des politiques. Cah. D'economie Sociol. Rural. INRA Ed. 2003, 67, 51-59.

42. Mlaouhi, S.; Ghanem, H.; Najar, A. Potential climate change impacts on Imen barley BYDV resistant variety yields in Tunisia. $J$ Agron. Agri. Sci. 2020, 3, 025.

43. Delécolle, R.; Ruget, F.; Ripoche, D.; Gosse, G. Effets possibles de modifications climatiques globales sur les cultures de blé et de maïs en France : Une étude de simulation. Doss. Environ. INRA 1994, 8, 183-190.

44. Zampieri, M.; Toreti, A.; Ceglar, A.; Naumann, G.; Turco, M.; Tebaldi, C. Climate resilience of the top ten wheat producers in the Mediterranean and the Middle East. Reg. Environ. Chang. 2020, 20, 41. [CrossRef]

45. Daloz, A.S.; Rydsaa, J.H.; Hodnebrog, Ø.; Sillmann, J.; van Oort, B.; Mohr, C.W.; Agrawal, M.; Emberson, L.; Stordal, F.; Zhang, T. Direct and indirect impacts of climate change on wheat yield in the Indo-Gangetic plain in India. J. Sci. Food Agric. 2021, 4, 100132

46. Knaepen, H. Climate Risk in Tunisia: Challenges to Adaptation in the Agri-Food System; Barcelona Centre for International Affairs (CIDOB): Barcelona, Spain, 2021; pp. 7-10.

47. Kapur, B.; Aydin, M.; Yano, T.; Koç, M.; Barutçular, C. Interactive effects of elevated $\mathrm{CO}_{2}$ and climate change on wheat production in the Mediterranean region. In Climate Change Impacts on Basin Agro-Ecosystems. The Anthropocene: Politik-Economics-SocietyScience; Watanabe, T., Kapur, S., Aydın, M., Kanber, R., Akça, E., Eds.; Springer: Cham, Switzerland, 2019; Volume 18, pp. 245-268.

48. Yana, N. Quel temps fera-t-il au xxie siècle? Références Maïs 1999, 6, 80-82.

49. Easterling, W.E.; Aggarwal, P.K.; Batima, P.; Brader, K.M.; Erda, L.; Howden, S.M.; Kirilenko, A.; Morton, J.; Soussana, J.F.; Schmidhuber, J.; et al. Food, fibre and forest product. In Climate Change 2007: Climate Change Impacts, Adaptation and Vulnerability. Contribution of Working Group ii to the Fourth Assessment Report of the Intergovernmental Panel on Climate Change; Parry, M.L., Canziani, O.F., Palutikof, J.P., van der Linden, P.J., Hanson, C.E., Eds.; Cambridge University Press: Cambridge, UK, 2007; pp. 273-313.

50. Bellia, S. Simulation des Impacts des Changements Climatiques Attendus sur la Production de la Culture du blé en Beauce. Master's Thesis, Université de Provence Aix-Marseille I, Marseille, France, 1999. 
51. Rosenzweig, C.; Tubiello, F.N. Effects of changes in minimum and maximum temperature on wheat yields in the central USA simulation study. Agric. For. Meteorol. 1996, 80, 215-230.

52. Yang, C.; Fraga, H.; van Ieperen, W.; Trindade, H.; Santos, J.A. Effects of climate change and adaptation options on winter wheat yield under rainfed Mediterranean conditions in southern Portugal. Clim. Chang. 2019, 154, 159-178. [CrossRef]

53. Asseng, S.; Martre, P.; Maiorano, A.; Rötter, R.P.; O’Leary, G.J.; Fitzgerald, G.J.; Girousse, C.; Motzo, R.; Giunta, F.; Babar, M.A.; et al. Climate change impact and adaptation for wheat protein. Glob. Chang. Biol. 2019, 25, 155-173. [CrossRef]

54. USDA. Soil Classification: A Comprehensives System (Prepared by) Soil Survey Staff; Government Printing Office: Washington, DC, USA, 2013.

55. Zadoks, J.C.; Chang, T.T.; Konzak, C.F. A decimal code for the growth stages of cereals. Weed Res. 1974, 14, 415-421. [CrossRef]

56. Stöckle, C.; Donatelli, M.; Nelson, R. CropSyst, a croping systems model. Eur. J. Agron. 2003, 18, 289-307. [CrossRef]

57. Nelson, R. ClimGen-Climatic Data Generator User's Manual; Biological Systems Engineering Department, Washington State University: Pullman, WA, USA, 2005.

58. Stöckle, C.; Nelson, R. Cropping Systems Simulation Model User's Manual; Biological Systems Engineering Department, Washington State University: Pullman, WA, USA, 2005. 